\title{
Nematological survey in coffee nursery in Espirito Santo state, Brazil
}

\author{
Maria Cecília Fonseca Scarpi ${ }^{1}$, Ângelo Oliveira Gonçalves ${ }^{1}$, Antônio Fernando de Souza², Guilherme de Resende \\ Camara $^{1}$, Willian Bucker Moraes ${ }^{1}$, Fábio Ramos Alves $^{1}{ }^{*}$ D \\ $10.1590 / 0034-737 X 202168020005$
}

\begin{abstract}
Despite the important role of coffee production in the economy of Espirito Santo, the second largest coffee producing state in Brazil, productivity is still below the Brazilian average. One of the factors that explain this low productivity is the presence of nematodes of the genus Meloidogyne. Contaminated seedlings are an important and efficient agent for disseminating nematodes. According to normative instruction no. 35 (IN 35), of 11/29/2012 of the Ministry of Agriculture, Livestock and Supply (MAPA), the presence of Meloidogyne spp. in a single plant among a field-lot of seedlings condemns it, and the plants that compose that lot should be destroyed. In Espirito Santo, no evaluation has been carried out in nurseries covering the entire State for phytonematode detection. Therefore, the objective of this work was to carry out a nematological survey in nurseries to guide the nurserymen in relation to fulfilling IN 35 of MAPA, in addition to guiding them regarding the phytosanitary care during the production of their seedlings. The nurseries were evaluated in 19 municipalities located in both the north and the south of Espírito Santo. There were Meloidogyne spp. in evaluated samples.
\end{abstract}

Keywords: nematodes; Coffea spp.; seedlings.

\section{INTRODUCTION}

Coffee farming plays a socioeconomic role of great importance for the State of Espírito Santo. According to data collected by the Capixaba Institute for Research, Technical Assistance and Rural Extension (Incaper), Espírito Santo harvested about 9 million sacks of coffee in 2016. Although the state continues to be the country's second largest coffee producer, productivity in Espírito Santo has historically always been below the Brazilian average, which is around 24 sc/ha (CONAB, 2017).

Many factors may be related to low coffee productivity, such as nematodes. The main species of nematodes associated with coffee tree belong to the genus Meloidogyne, with emphasis on $M$. incognita, $M$. paranaensis, M. exigua, and M. coffeicola (Barbosa, 2004; Contarato et al., 2014; Sera et al., 2017).
Barros et al. (2014) made a nematological survey in coffee fields in the State of Espírito Santo regarding the presence of Meloidogyne spp. in Coffea spp. and reported the presence of $M$. exigua, $M$. incognita and $M$. paranaensis, these latter two species being very aggressive to the coffee tree.

One of the most efficient agents to disseminate nematodes is contaminated seedlings, which makes it necessary to raise awareness about the preventive measures that should be taken by coffee nurseries regarding phytosanitary care during the production of their seedlings (Gonçalves \& Silvarola, 2001; Lordello et al., 2001).

Normative instruction no. 35 (IN 35) of 11/29/2012 of the Ministry of Agriculture, Livestock and Supply (MAPA) states that if, under laboratory analysis of coffee plants, the presence of Meloidogyne spp. is proven in a

\footnotetext{
Submitted on July $10^{\text {th }}, 2020$ and accepted on November $2^{\text {nd }}, 2020$

${ }^{1}$ Universidade Federal do Espírito Santo, Departamento de Agronomia, Alegre, Espírito Santo, Brazil. cissascarpi2@hotmail.com; angoligon@yahoo.com.br; camara.gdr@gmail.com; willian.fito@gmail.com; fabioramosalves@yahoo.com.br

${ }^{2}$ Instituto Federal de Educação, Ciência e Tecnologia do Espírito Santo, Campus Santa Teresa, Santa Teresa, Espírito Santo, Brazil. anfersouza@gmail.com.

*Corresponding author: fabio.alves@ufes.br
} 
field-lot of seedlings, the sample will be condemned and the seedlings will be destroyed.

Whereas no evaluation has been performed in nurseries covering the entire state of Espirito Santo regarding the presence of phytonematodes, this study aimed to carry out a nematological survey in nurseries, with the following goals: i) to ascertain the possible presence of phytonematodes in nurseries; ii) to guide the nurserymen about fulfilling IN 35 of MAPA; iii) to alert the nurserymen about the phytosanitary care they should employ during the production of their seedlings and, in this way, prevent the dissemination of phytonematodes in coffee farming areas in the State.

\section{MATERIAL AND METHODS}

The present project was performed between the years 2011 and 2013. During this period, nematological surveys were carried out in coffee farms implanted in the State of Espírito Santo and registered with the Agricultural Inspection Service - SEFAG/DT.

Samples from 85 nurseries were collected in 21 municipalities located in the north and south of Espírito Santo state, namely: Alegre, Anchieta, Brejetuba, Cachoeiro de Itepemirim, Castelo, Colatina, Conceição do Castelo, Guaçuí, Ibatiba, Ibitirama, Iconha, Iúna, Jaguaré, Linhares, Muniz Freire, Rio Bananal, Santa Teresa, São Gabriel da Palha, São Roque do Canaã, Sooretama and Venda Nova do Imigrante.

For collection of seedlings, sampling was performed following the recommendations of Salgado et al. (2007), as follows: a) the nurseries were divided into lots of a maximum of 200,000 seedlings; b) each lot was divided into four quadrants; c) in each quadrant, alternated seedbeds were selected for sampling and $0.1 \%$ of the seedlings were evaluated, with a minimum of 30 seedlings; d) each seedbed was divided into five sectors numbered from 1 to 5 , from the extremities. In the center of sectors 1 , 2, 4 and 5, two seedlings were removed. At the center of sector 3, four seedlings were removed; e) a composite sample was formed with all the plants from each quadrant, which were packed in plastic bags and labeled.

Subsequently, the samples were sent to the phytopathology/nematology laboratory of the Center of Agricultural Sciences and Engineering of UFES (CCAEUFES), where extractions and evaluation of soil and root samples were carried out for the presence of phytonematodes.

For the extraction of nematodes from the soil, the method of Jenkins (1964) was used, and for the root nematode extraction, the Coolen \& D'Herde technique (1972). After the extractions of soil and root nematodes were finished, the evaluations were done in an inverted trinocular biological microscope for identification at the genus level of phytonematodes with the aid of specific identification keys.

When nematodes of the genus Meloidogyne were found, the genus was confirmed only by the observation of second-stage juveniles (J2), because one of the main goals of the work was to guide the nurserymen in fulfilling IN 35 of MAPA, in which the presence of a single individual of the genus is sufficient to condemn the subplots, regardless of the species, so that the seedlings therein contained must be destroyed.

\section{RESULTS AND DISCUSSION}

Some nurseries that researchers expected to visit were not accessed because no one was found at the time of the visit.

It is very important to make nematological surveys not only in the field but also in nurseries, because despite the growing incentive for the production of quality coffee seedlings, Meloidogyne spp. were found in Ibatiba, Santa Teresa, Linhares, Rio Bananal, São Gabriel da Palha, Sooretama and Jaguaré (Table 1, Figures 1a, b, c, e, f, respectively), and Helicotylenchus sp. was present in Castelo and Venda Nova do Imigrante. According to Campos (1999), once introduced in the area, it is extremely difficult to manage phytonematodes of economic importance in perennial crops, such as coffee.

Normative instruction (IN) no. 35, of 11/29/2012 of the Ministry of Agriculture, Livestock and Supply (MAPA), states in Article 29 of Chapter III that 'the seedlings will be sampled before commercialization, in order to verify the existence of defective roots and Meloidogyne spp. It is further stated in Article 32 that in any subplot where the result of the analysis proves the presence of Meloidogyne spp. will be condemned and the seedlings must be destroyed by the producer. Article 34 reaffirms that 'the coffee seedling should be free from Meloidogyne spp'. According to this information, if the seedlings from nurseries where Meloidogyne spp. were present are submitted to an evaluation before a certificate of phytosanitary origin (CFO) is issued, those seedlings in the sub-plots where the nematodes were detected must be destroyed.

Barros et al. (2014) studied the distribution of Meloidogyne spp. in Coffea spp. in some properties of the main coffee farming regions in the State of Espírito Santo. M. incognita was present in $21 \%$ of the properties. This species, one of the most aggressive to the coffee tree, was mainly associated with $C$. canephora in fields in the northern and mountainous regions of the State. $M$. exigua was found mainly in C. arabica in $23.8 \%$ of the properties, and it was present in $66.6 \%$ of the municipalities of the mountainous region and in all the southern areas. M. paranaensis was present only in the north, and it was found in $100 \%$ of the properties of Baixo Guandu. 
Table 1: Municipalities of the State of Espirito Santo where evaluations were carried out for the presence of phytonematodes in coffee nurseries between the years 2011 and 2013. The municipalities were divided per region according to Law 11,174 of 09/25/2020

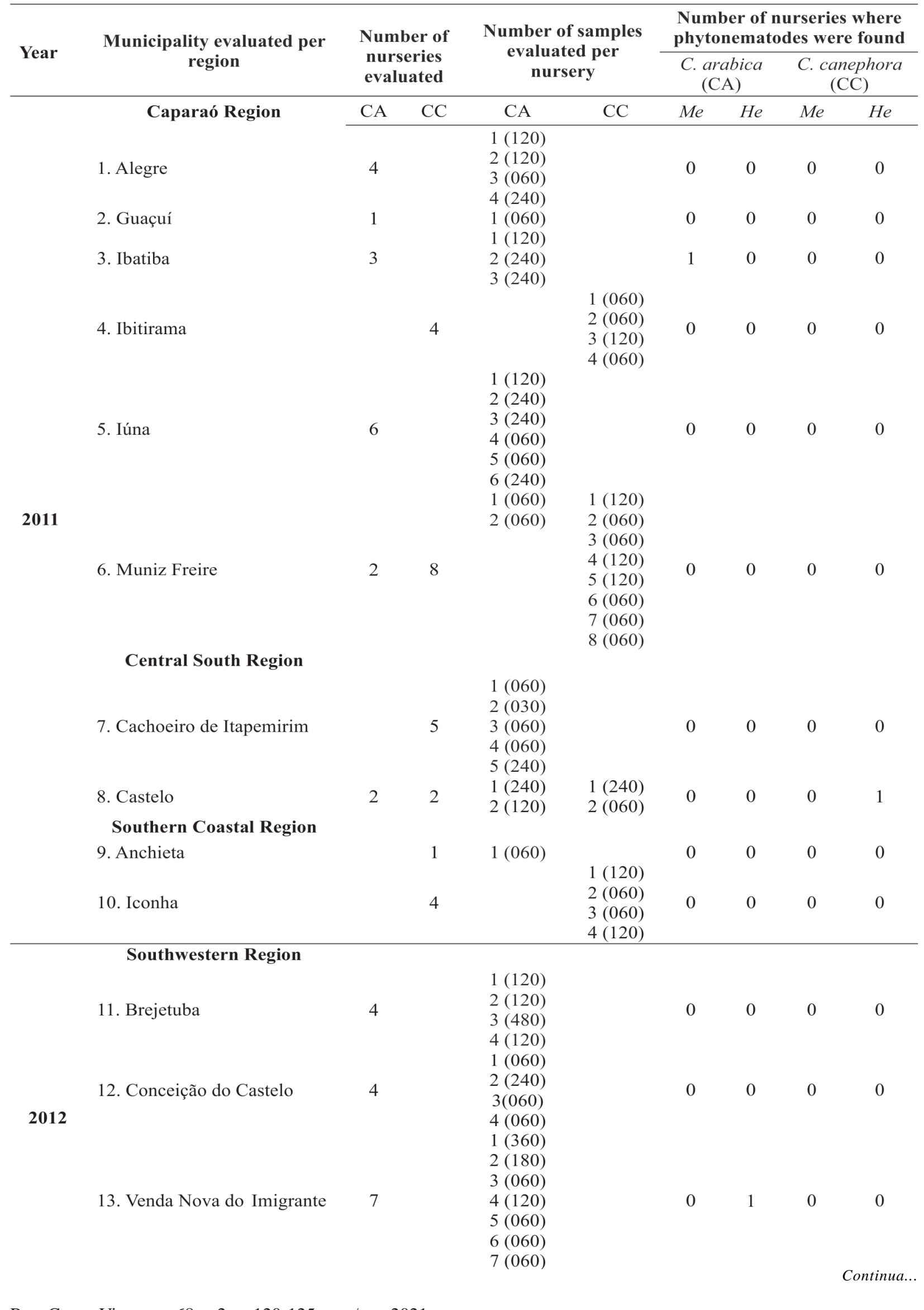


Continuação

\begin{tabular}{|c|c|c|c|c|c|c|c|c|c|}
\hline \multirow{6}{*}{ Year } & \multirow{3}{*}{$\begin{array}{c}\text { Municipality evaluated per } \\
\text { region } \\
\text { Central South Region }\end{array}$} & \multirow{2}{*}{\multicolumn{2}{|c|}{$\begin{array}{c}\text { Number of } \\
\text { nurseries } \\
\text { evaluated }\end{array}$}} & \multirow{2}{*}{\multicolumn{2}{|c|}{$\begin{array}{c}\text { Number of samples } \\
\text { evaluated per } \\
\text { nursery }\end{array}$}} & \multicolumn{4}{|c|}{$\begin{array}{l}\text { Number of nurseries where } \\
\text { phytonematodes were found }\end{array}$} \\
\hline & & & & & & \multicolumn{2}{|c|}{$\begin{array}{l}\text { C. arabica } \\
\text { (CA) }\end{array}$} & \multicolumn{2}{|c|}{$\begin{array}{l}\text { C. canephora } \\
\text { (CC) }\end{array}$} \\
\hline & & $\mathrm{CA}$ & $\mathrm{CC}$ & $\mathrm{CA}$ & $\mathrm{CC}$ & $M e$ & $\mathrm{He}$ & $M e$ & $\mathrm{He}$ \\
\hline & 14. Castelo & 4 & & $\begin{array}{l}1(120) \\
2(120) \\
3(240) \\
4(060)\end{array}$ & & 0 & 1 & 0 & 0 \\
\hline & \multicolumn{9}{|l|}{ Central Highlands Region } \\
\hline & 15. Santa Teresa & 2 & 4 & $\begin{array}{l}1(060) \\
2(060)\end{array}$ & $\begin{array}{l}1(240) \\
2(060) \\
3(060) \\
4(060)\end{array}$ & 0 & 0 & 1 & 0 \\
\hline \multirow{8}{*}{2013} & Midwest Region & & & & & & & & \\
\hline & 16. Colatina & 3 & & $\begin{array}{l}1(060) \\
2(120) \\
3(240) \\
1(120) \\
2(120)\end{array}$ & & 0 & 0 & 0 & 0 \\
\hline & 17. São Gabriel da Palha & 5 & & $\begin{array}{l}3(060) \\
4(120) \\
5(060)\end{array}$ & & 0 & 0 & 1 & 0 \\
\hline & $\begin{array}{l}\text { 18. São Roque do Canaã } \\
\text { Rio Doce Region }\end{array}$ & 1 & & $1(120)$ & & 0 & 0 & 0 & 0 \\
\hline & 19. Linhares & 3 & & $\begin{array}{l}1(120) \\
2(240) \\
3(120)\end{array}$ & & 0 & 0 & 1 & 0 \\
\hline & 20. Rio Bananal & 4 & & $\begin{array}{l}1(240) \\
2(120) \\
3(060) \\
4(060)\end{array}$ & & 0 & 0 & 2 & 0 \\
\hline & $\begin{array}{l}\text { 21. Sooretama } \\
\text { Northeast Region }\end{array}$ & 1 & & $1(060)$ & & 0 & 0 & 1 & 0 \\
\hline & 22. Jaguaré & 1 & & $1(120)$ & & 0 & 0 & 1 & 0 \\
\hline
\end{tabular}

Me: Meloidogyne sp.; He: Helicotylenchus sp.

This work performed by Barros et al. (2014) indicates that some of the most damaging nematodes for coffee cultivation are widely distributed in Espirito Santo and, if they continue to be disseminated in the State, coffee cultivation in Espirito Santo is at risk. Therefore, the crucial point during phytosanitary management in the State is the production of good quality seedlings that are free from phytonematodes.

In a study carried out by Lordello et al. (2001), soil samples and coffee roots were collected from 37 municipalities in the State of São Paulo, and breeds 1, 2 and 3 of M. incognita, M. exigua, M. paranaensis and $M$. javanica were found. The authors suggested that nematode dissemination might have occurred through seedlings.

Helicotylenchus sp. was observed in the municipalities of Castelo and Venda Nova do Imigrante. It is important to highlight that, although it is a nematode with a large geographic distribution, it is not damaging to the coffee crop (Tihohod, 1993).
In Espírito Santo, the areas that most present problems with $M$. paranaensis and mainly with $M$. incognita are found in the mountainous region and in the northern part of the State. A larger number of nurseries with the presence of phytonematodes are observed in these localities. The seedlings may be acting as disseminators of nematodes in these regions.

Before we started the visits to the nurseries at the beginning of this work, a questionnaire was produced with several questions that were asked during the sample collections in all the nurseries visited. These questions aimed to evaluate the level of technical knowledge of the nurserymen concerning the conduct of their nurseries. Here are some of the questions that were asked: i) what kind of substrate do you use in your nursery?; ii) if the substrate used contains soil, what is its origin and what kind of treatment do you perform?; iii) is there a technical expert responsible for the monitoring of your nursery during the production of your seedlings?; iv) are you aware of the soil pathogens that can be transmitted 


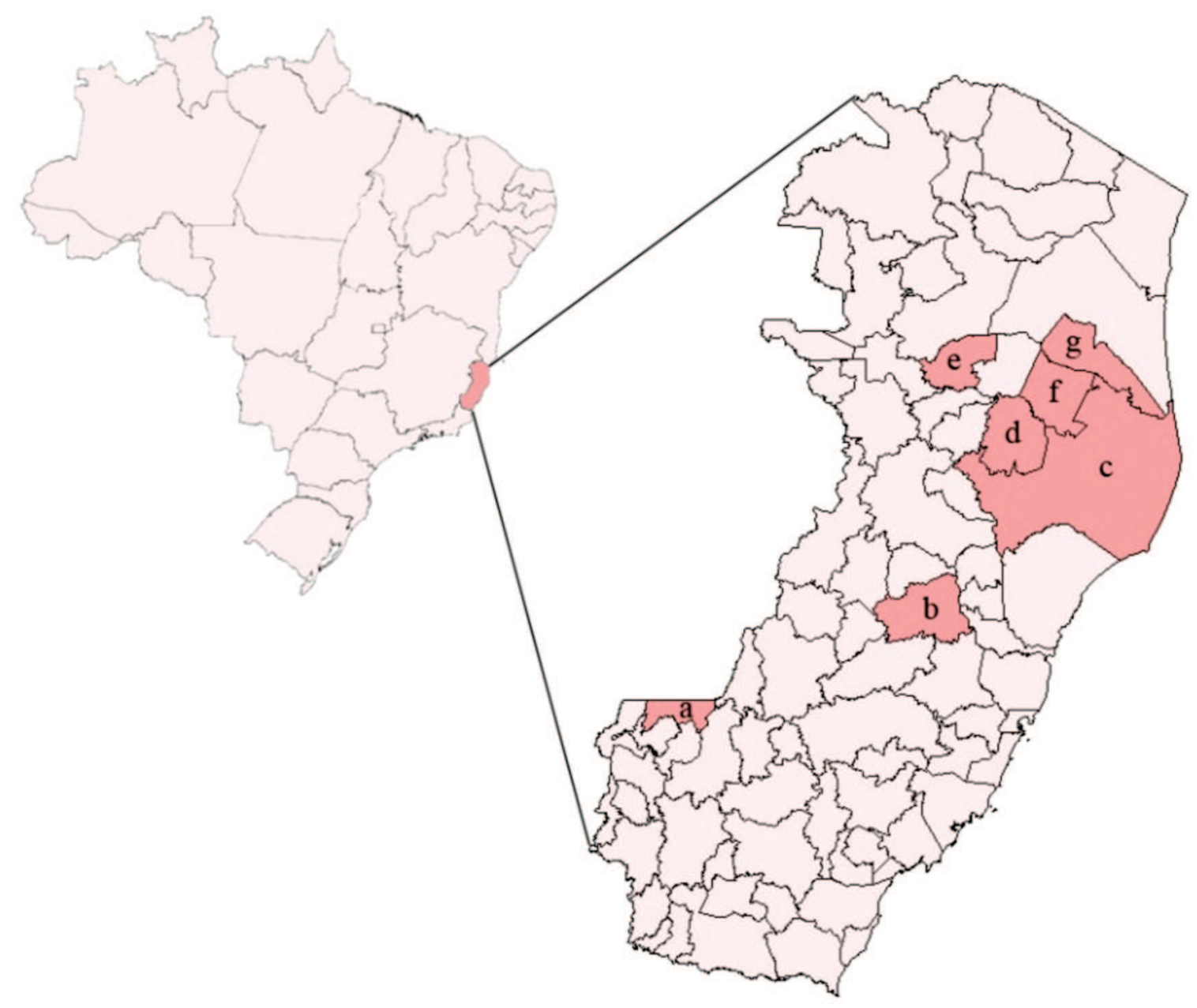

Figure 1: Municipalities of the State of Espirito Santo where second-stage juveniles (J2) of Meloidogyne spp. were present in coffee nurseries in a nematological survey carried out between the years 2011 and 2013. Meloidogyne spp. were present in Ibatiba (a), Santa Teresa (b), Linhares (c), Rio Bananal (d), São Gabriel da Palha (e), Sooretama (f) and Jaguaré (g).

through seedlings and the difficulties of controlling them after they are established in crop fields?

All nurseries answered that they use ravine or virgin forest soil without any type of treatment. All of them also stated that they have a technical expert responsible for their nursery and that they know nematodes can be transmitted by the seedlings and their management is difficult in the field. The seedlings of most nurseries evaluated in this study did not present phytoparasitic nematodes, probably because they receive adequate orientation regarding the phytosanitary aspects of a technical manager.

The use of virgin forest soil, common in nurseries in Espirito Santo, does not guarantee that such soils do not contain Meloidogyne spp. since there are reports of these pathogens in native areas in the Atlantic Forest (Lima et al., 2005, Carneiro et al., 2006a, 2006b). Thus, it is suggested that nurserymen who use soil from the Atlantic Forest of Espírito Santo to produce their seedlings should treat this substrate.
It is concluded with this work that although phytonematodes have been found in only a few nurseries, it is necessary to observe the choice of the substrate, irrigation water and other phytosanitary care. Most nurserymen in Espírito Santo produce their seedlings in direct contact with the soil. This is a situation that needs to be changed, and it is necessary for nursery owners to be aware that to be safer regarding the dissemination of nematodes and other soil pathogens, these seedlings need to be produced suspended on benches.

Finally, it is important to note that during the visits to the State nurseries, a small number of clandestine nurseries were registered with the SEFAG/DT. These nurseries are a risk to coffee cultivation because they are managed without technical criteria that take into consideration all essential phytopathological care to avoid the dissemination of phytonematodes in Espírito Santo State nurseries should not purchase seedlings from these nurseries. 


\section{CONCLUSIONS}

We have detected the presence of Meloidogyne spp. in nurseries located in the north and south of Espírito Santo, which is very worrying information, since coffee growing is of great socio-economic importance for Espirito Santo and the main species, ie M. exigua, M. incognita e M. paranaensis may be being spread by seedlings and reducing the productive potential of crops in this state.

\section{ACKNOWLEDGEMENTS, FINANCIAL SUPPORT AND FULL DISCLOSURE}

We are grateful to Fundação de Apoio a Pesquisa, Ensino e Extensão (FINEP) and Fundação de Amparo à Pesquisa e Inovação do Espírito Santo (FAPES) for financial support and the Nucleus of Scientific and Technological Development in Phytosanitary Management of Pests and Diseases (NUDEMAFI), Federal University of Espirito Santo (UFES), for support in carrying out the research work.

The authors declare that there is no conflict of interest in the conduct and publication of this work.

\section{REFERENCES}

Barbosa DHSG, Vieira HD, Souza RM, Viana AP \& Silva CP (2004) Fields estimates of coffee yield losses and damage threshold by Meloidogyne exigua. Nematologia Brasileira, 28:49-54.

Barros AF, Oliveira RDL, Lima IM, Coutinho RR, Ferreira AO \& Costa A (2014) Root-knot nematodes, a growing problem for conilon coffee in Espírito Santo state, Brazil. Crop Protection, $55: 74-79$

Campos VP (1999) Manejo de doenças causadas por fitonematoides. Lavras, UFLA. 106p.

Carneiro RMDG, Almeida MRA, Braga RS, Almeida CA \& Gioria R (2006a) Primeiro registro de Meloidogyne mayaguensis parasitando plantas de tomate e pimentão resistentes à meloidoginose no estado de São Paulo. Nematologia Brasileira, 30:81-86.

Carneiro RMDG, Mônaco APA, Mortiz MP, Nakamura KC \& Scherer A (2006b) Identificação de Meloidogyne mayaguensis em goiabeira e em plantas invasoras, em solo argiloso, no estado do Paraná. Nematologia Brasileira, Piracicaba, 30:293-298.

CONAB - Companhia Nacional de Abastecimento (2018) Acompanhamento da safra brasileira: café - Primeiro levantamento Janeiro. Available at: <http://www.conab.gov.br/OlalaCMS/ uploads/arquivos/18_01_24_17_34_27_cafe_janeiro2018.pdf >. Accessed on: April, 5 ${ }^{\text {th }}, 2017$.

Contarato CC, Tomaz MA, Alves FR, Sobreira FM, Jesus Junior WC, Rabello LKC, Ferrão MAG \& Ferrão RG (2014) Reaction of cultivar coffee Vitória INCAPER 8142 of conillon to parasitism of Meloidogyne exigua. Idesia, 32:93-97.

Coolen WA \& D'Herde CJ (1972) A method for the quantitative extraction of nematodes from plant tissue. Ghent, State Nematology and Entomology Research Station. 77p.

Gonçalves W \& Silvarolla MB (2001) Nematóides parasitos do cafeeiro. In: Zambolim L. (Ed.) Tecnologias de produção de café com qualidade. Viçosa, UFV. p. 199-267.

Jenkins WR (1964) A rapid centrifugal - flotation technique for extracting nematodes from soil. Washington, Plant Disease Report. 692p.
Lima IM, Souza RM, Silva CP \& Carneiro RMDG (2005) Meloidogyne spp. from preserved areas of Atlantic Forest in the State of Rio de Janeiro, Brazil. Nematologia Brasileira, 29:31-38.

Lordello AIL, Lordello RRA \& Fazuoli LC (2001) Levantamento de espécies de Meloidogyne em cafeeiros no estado de São Paulo. In: II Simpósio de Pesquisa dos cafés do Brasil, Vitória. EMBRAPA. p.1182-1187.

Salgado SML, Pinheiro JB \& Oliveira RDL (2007) Metodologia de amostragem em viveiro e em lavoura cafeeira para análise de nematoides. Belo Horizonte, EPAMIG. 5p.

Sera T, Sera GH, Fazuoli LC, Machado ACZ, Ito DS, Shigueoka LH \& Silva SA (2017) IPR 100 - Rustic dwarf arabica coffee cultivar with resistance to nematodes Meloidogyne paranaensis and M. incognita. Crop Breeding and Applied Biotechnology, 17:175179.

Tihohod D (1993) Nematologia agrícola aplicada. Jaboticabal, FUNEP/UNESP. 372p. 